\section{Formation of the Inclusive Environments and Metrics in Biology Education and Research (iEMBER) Network: Building a Culture of Diversity, Equity, and Inclusion}

Rachel E. Tennial, ${ }^{\dagger}$ Erin D. Solomon, ${ }^{\ddagger}$ Latanya Hammonds-Odie, $\$$ Gary S. McDowell,"ศr Michael Moore,"\|\# Alberto I. Roca,"@ and Jana Marcette*** ${ }^{\dagger}$ Department of Psychology, University of Arkansas at Little Rock, Little Rock, AR 72204; ${ }^{\text {CCenter }}$ for Integrative Research on Cognition, Learning, and Education, Washington University in St. Louis, St. Louis, MO 63130; \$School of Science and Technology, Georgia Gwinnett College, Lawrenceville, GA 30046; "Future of Research, Abington, MA 02351; "Department of Biology, Baylor University, Waco, TX 76706; ${ }^{\circledR}$ DiverseScholar, Irvine, CA 92616; ${ }^{* *}$ Department of Mathematics and Natural Sciences, Harris-Stowe State University, St. Louis, MO 63103

\begin{abstract}
The Inclusive Environments and Metrics in Biology Education and Research (iEMBER) network is a newly forming national community of practice that engages diversity, equity, and inclusion stakeholders in interdisciplinary collaborative projects. iEMBER was initiated with incubator funding from the National Science Foundation program for Research Coordination Networks in Undergraduate Biology Education. In June 2017, biology education researchers, social scientists, biologists, and program and policy administrators, all with interests in diversity, equity, and inclusion, met to lay the foundation for the iEMBER network. iEMBER provides a distinct forum to coordinate efforts through networking, professional development, and the initiation of collaborative research. iEMBER advances science, technology, engineering, and mathematics reform focused on diversity, equity, and inclusion through the initiation of research teams at the iEMBER biennial conference and outreach efforts at discipline-specific meetings and conferences. The focus of iEMBER is on understanding how to create inclusive, supportive, and engaging environments to foster the success of all biology students and trainees. This report focuses on the structure of the iEMBER network, two takeaways that emerged from the 2017 conference (interdisciplinary networking/collaboration and intradisciplinary broadening participation strategies), and ways for prospective members to engage in ongoing dialogue and future events. Learn more at http://iember.org.
\end{abstract}

\section{INTRODUCTION}

The U.S. population and workforce are becoming increasingly diverse, yet underrepresentation in science, technology, engineering, and mathematics (STEM) fields has remained stubbornly persistent (National Science Foundation, National Center for Education Statistics, 2017). Broadening participation in STEM can both increase diversity in the STEM workforce and address the projected deficit in qualified workers to meet the needs of a growing STEM-based economy (President's Council of Advisors on Science and Technology, 2012). Additionally, research has shown that more diverse research labs are more productive than those that are homogeneous (AlShebli et al., 2018). Furthermore, broadening participation will be required to sustain and grow biomedical research communities (Pickett et al., 2015; Gibbs et al., 2016). Interestingly, among Latinos, African Americans, and Native Americans who enter postsecondary education, enrollment in STEM programs is roughly equal to the national average for all students (Hurtado et al., 2010). However, individuals from
CBE Life Sci Educ March 1, 2019 18:mr1 DOI:10.1187/cbe.18-03-0042

"These authors contributed equally to this work. *Address correspondence to: Jana Marcette (marcettjahssu.edu)

(C) 2019 R. E. Tennial et al. CBE-Life Sciences Education (c) 2019 The American Society for Cell Biology. This article is distributed by The American Society for Cell Biology under license from the author(s). It is available to the public under an Attribution-Noncommercial-Share Alike 3.0 Unported Creative Commons License (http://creativecommons.org/licenses/ by-nc-sa/3.0)

"ASCB®" and "The American Society for Cell Biology ${ }^{\circledR}$ " are registered trademarks of The American Society for Cell Biology. 
TABLE 1. Fall 2018 to Spring 2019 iEMBER events at discipline-specific meetings and conferences

\begin{tabular}{|c|c|c|c|c|}
\hline Conference/meeting & Dates & Location & Event & iEMBER contact \\
\hline $\begin{array}{l}\text { Society for the Advancement of Biology } \\
\text { Education Research } 2018 \text { National } \\
\text { Meeting }\end{array}$ & July 27-29, 2018 & Twin Cities, MN & Sessions (accepted) & $\begin{array}{l}\text { Dr. Heather Heinz } \\
\text { (hheinz@uw.edu) }\end{array}$ \\
\hline $\begin{array}{l}\text { Center for Integrative Research on } \\
\text { Cognition, Learning, and Education } \\
2018 \text { Conference }\end{array}$ & Sept. 6-7, 2018 & St. Louis, MO & Poster/informal event & $\begin{array}{l}\text { Dr. Jana Marcette } \\
\quad \text { (marcettj@hssu.edu) }\end{array}$ \\
\hline $\begin{array}{l}\text { Society for Advancement of Chicanos/ } \\
\text { Hispanics and Native Americans in } \\
\text { Science } 2018 \text { Conference }\end{array}$ & Oct. 11-13, 2018 & San Antonio, TX & Poster/informal event & $\begin{array}{l}\text { Dr. Alberto Roca } \\
\text { (info@DiverseScholar.org) }\end{array}$ \\
\hline $\begin{array}{l}\text { Society for the Teaching of Psychology } \\
2018 \text { Conference on Teaching }\end{array}$ & Oct. 19-20, 2018 & Phoenix, AZ & Session (applied) & $\begin{array}{l}\text { Dr. Rachel Tennial } \\
\quad \text { (retennial@ualr.edu) }\end{array}$ \\
\hline $\begin{array}{l}\text { Association of American Colleges \& } \\
\text { Universities } 2018 \text { Transforming } \\
\text { STEM Higher Education Conference }\end{array}$ & Nov. 8-10, 2018 & Atlanta, GA & Session (accepted) & $\begin{array}{l}\text { Dr. Candice Idlebird } \\
\quad \text { (idlebirc@hssu.edu) }\end{array}$ \\
\hline $\begin{array}{l}\text { National Association of Biology Teachers } \\
2018 \text { Conference }\end{array}$ & Nov. 8-11, 2018 & San Diego, CA & Poster/informal event & $\begin{array}{l}\text { Dr. Michael Moore } \\
\text { (michael_e_moore@ baylor.edu) }\end{array}$ \\
\hline $\begin{array}{l}\text { American Society for Cell Biology } 2018 \\
\text { ASCB/EMBO Meeting }\end{array}$ & Dec. 8-12, 2018 & San Diego, CA & Session (accepted) & $\begin{array}{l}\text { Dr. Alison Crowe } \\
\text { (acrowe@uw.edu) }\end{array}$ \\
\hline $\begin{array}{l}\text { Midwestern Psychological Association } \\
\text { Meeting }\end{array}$ & April 11-13, 2019 & Chicago, IL & Sessions not yet open & $\begin{array}{l}\text { Dr. Richard Harvey } \\
\text { (harveyr@slu.edu) }\end{array}$ \\
\hline iEMBER 2019 Conference & April, 5-6, 2019 & St. Louis, MO & Entire conference & $\begin{array}{l}\text { Dr. Jana Marcette } \\
\quad \text { (marcettj@hssu.edu) }\end{array}$ \\
\hline $\begin{array}{l}2019 \text { Gordon Conference on Undergrad- } \\
\text { uate Biology Education Research }\end{array}$ & June 23-28, 2019 & Lewiston, ME & $\begin{array}{l}\text { Sessions not yet open; } \\
\text { poster/informal }\end{array}$ & $\begin{array}{l}\text { Dr. Uwe Hilgert } \\
\text { (hilgert@email.arizona.edu) }\end{array}$ \\
\hline
\end{tabular}

underrepresented groups are most likely to leave STEM fields at two particular checkpoints: graduating with an undergraduate STEM degree and the postdoc to faculty transition (Meyers et al., 2018). Overall, less than $40 \%$ of all students who enter STEM degree programs complete their degrees (National Center for Education Statistics, 2013), and a variety of perceptions and social and academic integration, rather than student abilities, seem to be critical factors in these decisions (Seymour and Hewitt, 1997; Graham et al., 2013).

Biology education mirrors other STEM fields, and there is a need for evidence-based solutions to increase persistence. Stakeholders are increasingly interested in understanding and assessing social-emotional and noncognitive factors that influence undergraduate student retention and success (Dolan, 2013; Dye and Stanton, 2015; Peffer and Renken, 2016; Shin et al., 2016). Critical research areas include understanding and promoting inclusion and equity in educational environments and understanding the psychological factors underpinning the success of educational pedagogies (Bensimon, 2005; Perna et al., 2009; Yeager and Walton, 2011; Dolan, 2013; Wang and Degol, 2013; Aguilar et al., 2014; Ribera et al., 2015). The formation of collaborative partnerships between biology education research and social sciences is a promising way to facilitate this paradigm shift (Dolan, 2017; Shipley et al., 2017). Interdisciplinary approaches expand knowledge in research communities beyond traditional boundaries and are a policy priority (Huerta et al., 2005), but breaking into the knowledge traditions of other disciplines is not easily accomplished (Frost and Jean, 2001). The creation of the Inclusive Environments and Metrics in Biology Education and Research (iEMBER) network provides a forum for interdisciplinary evidence-based solutions.

Much work on diversity, equity, and inclusion in STEM focuses on professional development for students and faculty.
The iEMBER network builds capacity beyond the current achievements by nurturing interdisciplinary collaborative teams. Teams consist of stakeholders from the social, educational, and biological sciences, as well as policy and STEM program administrators. Few organizations catalyze new interdisciplinary research through bringing social, educational, and biological scientists together with policy and program administrators, and to our knowledge, none have outreach efforts with national societies. iEMBER is particularly interested in engaging individuals who are not connected with the diversity, equity, and inclusion community. iEMBER members will engage through presentations and meet-ups at national, disciplinespecific conferences and meetings in the social, biology education, and biological sciences (see Table 1). This meeting report presents the structure of the iEMBER network, takeaway strategies that emerged from the 2017 iEMBER meeting (Interdisciplinary Collaboration, and Strategies for Broadening Intradisciplinary Participation) and details future iEMBER events and how to become involved with this new organization.

\section{STRUCTURE OF THE IEMBER INTERDISCIPLINARY NETWORK AND COMMUNITY OF PRACTICE}

To address the need for interdisciplinary collaboration, stakeholders in biology education and social sciences, STEM program and policy administrators, and biologists created the iEMBER network. These stakeholders share a key common focus on enhancing diversity, equity, and inclusion. iEMBER uses a community of practice framework, in which interdisciplinary members build relationships while working on shared projects. The iEMBER group was inaugurated in June of 2017 with a small national conference that generated three new research working groups (see Table 2, A and B). In addition to interdisciplinary research, iEMBER fosters awareness of 
TABLE 2A. 2017 iEMBER conference sessions

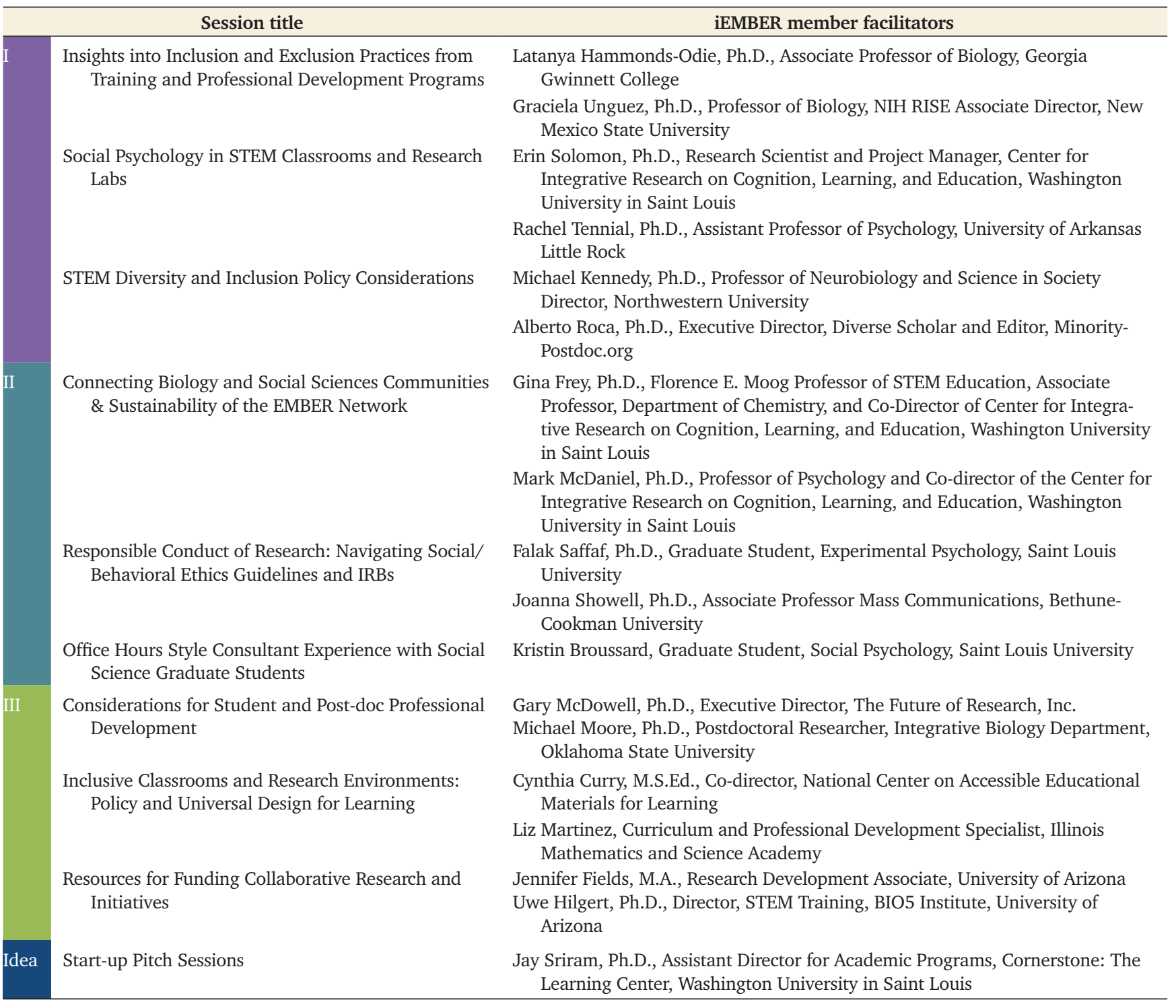

diversity, equity, and inclusion efforts at discipline-specific conferences and meetings (see Table 1).

iEMBER welcomes the involvement of early-career members. Junior faculty, postdocs, and graduate students are not just recipients of professional development but are welcome partners and leaders in projects and initiatives. We recognize that many other organizations discourage junior members from serving on committees and taking leadership positions. This perspective holds to the belief that graduate students, postdocs, and junior faculty need to focus on being successful in their research careers, often measured as attaining tenure, before engaging in such service. We believe such exclusionary policies, even when stemming from the best intentions, send messages about organizational and social belonging that are a disservice to the greater STEM enterprise. Our fundamentally different viewpoint is premised on three aspects of the iEMBER network: inclusion, interdisciplinary research, and teaching. First, iEMBER is founded on inclusion, and we strongly believe that

TABLE 2B. 2017 iEMBER and SPARC Awards for collaborative research working groups

\begin{tabular}{lll}
\hline Title & Award & \multicolumn{1}{c}{ Discipline perspectives represented } \\
\hline Piloting a Simple Intervention to Promote Student Self-Identification as Scientists & iEMBER & Biology, biology education, policy, psychology \\
Involving Postdocs, Family, and Students in a Mentoring Triad for Trainee Success & SPARC & Biology, policy, program director \\
Identifying Critical Periods for Growth Mindset Intervention & SPARC & Biology, biology education, program director \\
\hline
\end{tabular}




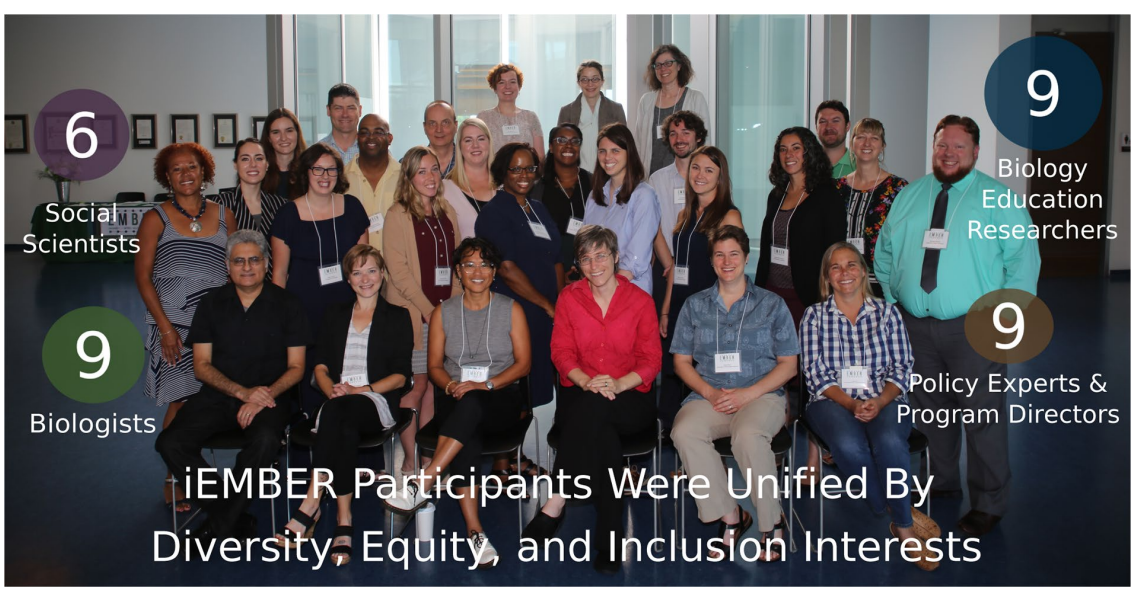

FIGURE 1. 2017 iEMBER conference group photo.

individual members are in the best position to evaluate their own context, including expectations and capacity for scholarship, teaching, and/or service. Second, for many organizations, diversity, equity, and inclusion efforts are service projects; for iEMBER, these efforts are interdisciplinary collaborative research. Additionally, our efforts presenting at conferences are a valued part of academic scholarship. For example, iEMBER member Dr. Jana Marcette is an assistant professor at a small public university. In her tenure requirements, research presentations at scholarly conferences that promote collaboration and exchange of ideas weigh equally with research publications (both at $6.25 \%$ of the total points evaluated to achieve tenure). Furthermore, many iEMBER members are interested in diversity, equity, and inclusion work, because it directly impacts their teaching performance, a major component of evaluation and promotion for educators.

The iEMBER network is grounded in Vision and Change action items for undergraduate biology education (Bauerle, 2011). Specifically, iEMBER believes the assessment of learning spaces, as a recognized part of individual courses and professional development success, should occur within scientific research communities that engage with each other and hold regularly scheduled conferences (Bauerle, 2011). The iEMBER network is one such community for individuals interested in promoting diversity, equity, and inclusion. iEMBER members will continue to engage one another and reach out to others at national/regional conferences and allow members the flexibility to contribute on several levels. For members who wish to know about ongoing initiatives, but do not wish to commit to a specific project, we have a newsletter that includes a directory of members and idea lists for upcoming projects. Members who are looking to become more involved can join a working group or connect to the interaction forum through our website http://iember.org. iEMBER welcomes new members looking to engage in a community of practice to examine, reflect, and act on diversity, equity, and inclusion evidence.

\section{7 iEMBER CONFERENCE}

The inaugural 2017 iEMBER national conference included a diverse group of participants representing institutions of many sizes, hailing from the Midwest, Northeast, South, and West geographic regions of the United States (see Figure 1 and Supplemental Figure S1). To cultivate community building with the network, participants boarded together on the campus of Harris-Stowe State University. Professional development at the conference included sharing best practices, ideas, and areas of interest related to expanding diversity, equity, and inclusion from the distinct communities represented by iEMBER members. The conference featured sessions that included co-led seminars followed by an interactive activity and roundtable discussion (see Table 2A). To chronicle the conference, selected content was disseminated through live and archived social media: \#EMBER2017 (Roca, 2017). The iEMBER conference also employed an innovative networking strategy combining elements of an entrepreneurial "start-up" weekend (Nager et al., 2011). A research "idea" start-up pitch competition was woven into the conference. Members developed initial ideas in randomly assigned groups, re-sorted themselves into working groups, and competed for iEMBER or SPARC (Supported Preliminary Award for Research Collaboration) awards (see Table 2, A and B) on the final day of the conference. iEMBER awards were given for one member to host others at his or her own institution for continued collaboration. SPARC awards were given for members to meet at a conference to further develop ideas.

\section{7 iEMBER CONFERENCE TAKEAWAY 1: INTERDISCIPLINARY NETWORKING AND COLLABORATION STRATEGIES}

Members who attended the conference stressed the need to break down silos separating researchers from one another and from the wider scientific community. Researchers who feel siloed on their campuses and within their discipline-specific communities need a professional network that fosters these connections and assists in forming collaborations. iEMBER members remarked upon an absence of mechanisms for communication among social sciences, discipline-based education research, and communities focused on broadening participation in STEM. Members noted that these communities attend different conferences, have separate professional development networks, and publish in distinct journals. Even the language used to describe common interests can be different, creating additional stumbling blocks to collaboration. For example, biology educators may be interested in student engagement, but not necessarily know that they have common interests with social scientists on their own campus who study engagement or concepts similar to engagement (e.g., locus of control or achievement motivation). To address this potential barrier for crossfield collaboration, iEMBER members have aligned some common interests between the biology education and social science communities. These listings are not meant to be exhaustive (see Table 3).

To create a community that bridges disciplines, iEMBER members decided to focus on opportunities for sustained, 
TABLE 3. Current biology education topics and how they relate to social science

\begin{tabular}{|c|c|c|}
\hline Biology education topic & Related social science topic(s) & Social scientist who may know more \\
\hline Addressing misconceptions & $\begin{array}{l}\text { Critical thinking, persuasion, attitude } \\
\text { formation, attitude change }\end{array}$ & $\begin{array}{l}\text { Social or developmental psychologist, } \\
\text { sociologist }\end{array}$ \\
\hline $\begin{array}{l}\text { Developing concept tests/content knowledge } \\
\text { tests }\end{array}$ & $\begin{array}{l}\text { Scale development, test construction, } \\
\text { alternative learning assessment } \\
\text { development }\end{array}$ & $\begin{array}{l}\text { Educational psychologist (or a psychologist } \\
\text { with scale development/measurement } \\
\text { background) }\end{array}$ \\
\hline Discovery-based teaching/labs & $\begin{array}{l}\text { Intrinsic motivation, active learning, } \\
\text { experiential learning }\end{array}$ & $\begin{array}{l}\text { Developmental, educational, social, or } \\
\text { industrial/organizational psychologist or } \\
\text { social scientist engaged in scholarship of } \\
\text { teaching and learning research }\end{array}$ \\
\hline Diversity & Stereotypes, attitudes & Social psychologist \\
\hline Engagement & Achievement motivation, Locus of control & Social psychologist, educational psychologist \\
\hline Evolution acceptance & Persuasion & Social psychologist \\
\hline Graduate student teaching development & Graduate professional development & $\begin{array}{l}\text { A social scientist that works with graduate } \\
\text { students (primarily at the doctoral level) }\end{array}$ \\
\hline Inclusion & $\begin{array}{l}\text { Social belonging, need to belong, stereotype } \\
\text { threat }\end{array}$ & Social psychologist \\
\hline Learning assistants & Relatedness, zone of proximal development & $\begin{array}{l}\text { Developmental psychologist, cognitive } \\
\text { psychologist }\end{array}$ \\
\hline Mentoring & Mentoring & $\begin{array}{l}\text { A social scientist that works with } \\
\text { undergraduate/graduate students }\end{array}$ \\
\hline Peer discussion & Active-learning techniques, constructivism & $\begin{array}{l}\text { A social scientist engaged in scholarship of } \\
\text { teaching and learning research }\end{array}$ \\
\hline Quantitative skills & Quantitative statistical analysis & $\begin{array}{l}\text { Developmental, educational, social, or } \\
\text { industrial/organizational psychologist }\end{array}$ \\
\hline Undergraduate research experiences & Undergraduate research & $\begin{array}{l}\text { A social scientist actively engaged in research } \\
\text { who works with undergraduate students }\end{array}$ \\
\hline
\end{tabular}

ongoing interactions. During the 2017-2018 academic year, iEMBER members met at the 2017 Gordon Conference on Undergraduate Biology Education Research and the 2018 Society for the Advancement of Biology Education ResearchSABER West conference. iEMBER members also worked in interdisciplinary teams to present a session at the 2017 National Association of Biology Teachers conference and hosted a booth at the 2018 Midwestern Psychological Association conference. In the 2018-2019 academic year, iEMBER will host its biennial conference, present sessions, and have coordinated attendance at discipline-specific national and regional meetings (see Table 1). Long-term priorities to foster an interdisciplinary, collaborative network include attending and presenting at discipline-specific professional society meetings and creating a sustainable platform of iEMBER regional and national meetings for generating working groups, professional development, and networking.

\section{STRATEGIES FOR BROADENING INTRADISCIPLINARY PARTICIPATION}

To increase inclusion and broaden participation within our fields, iEMBER members discussed leveraging existing resources and networks through membership and active engagement in professional societies. Professional societies play a big role in the development of professional identity by allowing individuals to connect across common interests on a national scale. Professional societies can also be a source of support or alienation for underrepresented students and professionals (Morris and Washington, 2017). Before the 2017 conference, each member was asked to identify one professional society in which he or she is an active member and to explore that society's website to look for evidence of a policy on diversity and/or inclusion. At the conference, iEMBER members Dr. Gabriela Unguez and Dr. Latanya Hammonds-Odie led a session in which iEMBER members discussed the central question "What is your primary scientific society doing to enhance diversity in science?" The session began with a listing of the professional societies to which members belonged, and members indicated whether those societies' websites mentioned the terms "diversity" or "inclusion" and/or carried a formal statement about inclusion/diversity (see Figure 2 and Supplemental Figure S2). The diagram in Figure 2 represents the collective findings of the iEMBER group. We recognize that this analysis is limited to the public Internet profile of these organizations and may not reflect policies and activities kept internal to the societies via members-only bylaws, newsletters, communications, and conference attendance. However, this analysis reflects the public face and a primary entry point for a potential society member who would not be familiar with the standards of practice among longtime professional members. On the basis of the society website analysis, we developed action recommendations that include both collective and individual leadership (see Supplemental Figure S3).

While many organizations had diversity/equity/inclusion/ minority(ies) and/or women's committees, iEMBER members reported finding few instances in which activities or outcomes of diversity, equity, and/or inclusion efforts were presented as a core component of the organization. A professional society focused on promoting a more diverse STEM world must have membership that that is emblematic of that effort. Low levels of diversity in the executive councils/top leadership of 


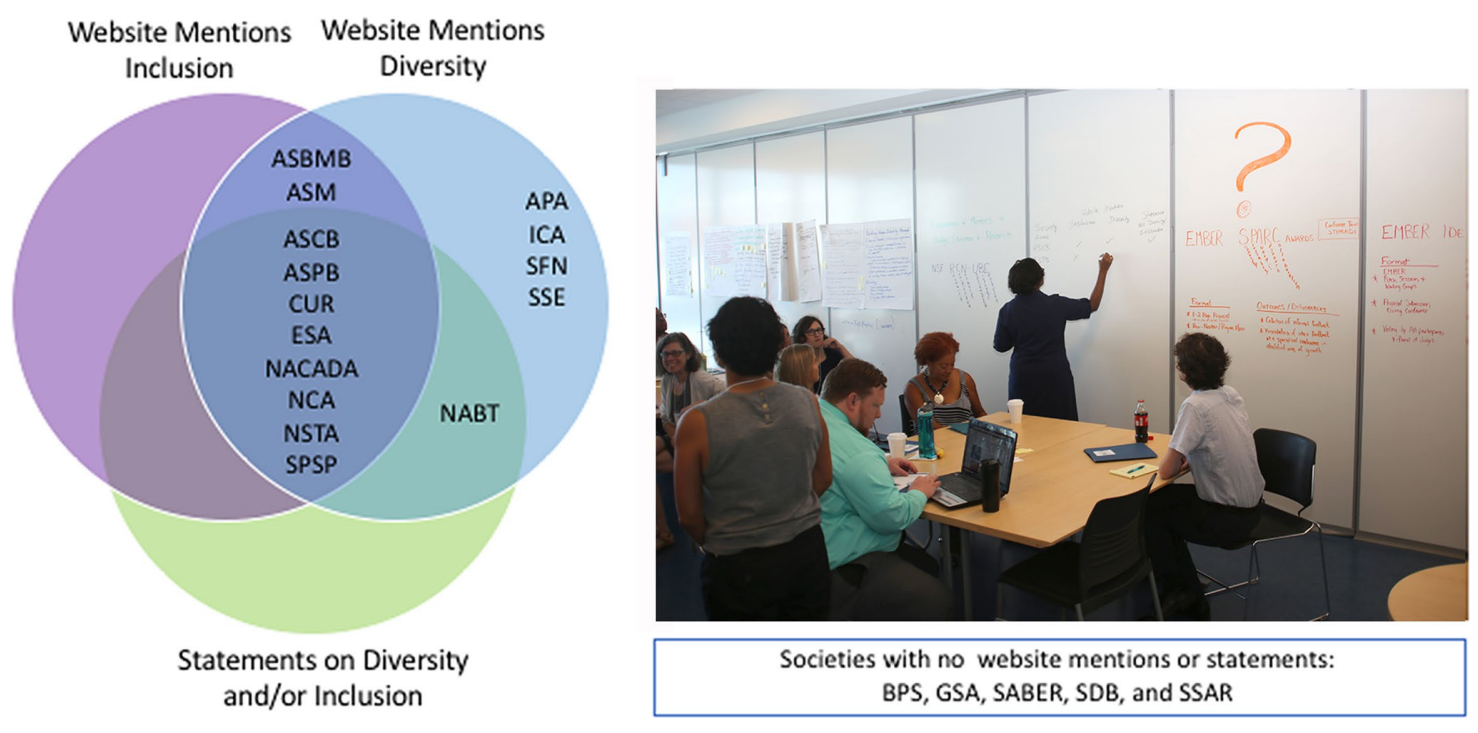

FIGURE 2. 2017 iEMBER conference session on diversity and inclusion in professional societies.

professional societies were noted by many iEMBER members, and this has been highlighted by Future of Research in their Who's on Board? initiative focusing on diversifying boards/ decision-making bodies through the inclusion of early-career researchers. Early-career researchers are at a critical juncture in establishing their own track records. However, participation in leadership opportunities of short duration can be beneficial to these individuals, provided the society is mindful of the burden of service required. Many colleges and universities value and reward the contributions that trainees and early-career professionals make toward inclusion and diversity in the context of professional societies as criteria for promotion.

We posit that when society leadership reflects the diverse nature of the membership, it is more likely that meetings will be structured in a way that broadens and maximizes participation and engagement of both early-career and more senior members. DiverseScholar/minoritypostdoc.org maintains a roster of the more than 70 diversity "stakeholder" professional societies (Minority Postdoc, 2018). These kinds of societies were established primarily with a mission to diversify the profession and can serve as a model for how all professional societies can be attentive to the ideals of diversity, equity, and inclusion.

\section{WHAT WE WILL DO NEXT}

The next steps of the iEMBER network are as follows: 1) increase the number and diversity of the iEMBER membership; 2) support ongoing iEMBER research projects while facilitating the formation of new research partnerships; and 3) connect with discipline-specific communities. In addition to focusing on inclusion, these steps also have the overarching goal of bringing together groups of people who do not usually meet together, thereby furthering the mission of the National Science Foundation program for Research Coordination Networks in Undergraduate Biology Education.

To increase the numbers and diversity of the iEMBER membership, we will focus on targeted recruiting as well as providing attractive resources and leadership opportunities. Going forward, iEMBER will be working to include more members from small and medium-sized institutions and those from the northeastern and southern regions of the United States. Through a focus on providing accessible research networking and professional development opportunities that are equally beneficial to faculty, postdocs, and graduate students, iEMBER helps to fill gaps in preparing instructors and other stakeholders to address diversity, equity, and inclusion.

The second step of the iEMBER network will focus on supporting current iEMBER research projects while being a conduit for the formation of future research partnerships. Following the success of the first meeting, iEMBER members have engaged in a variety of collaborations. Research working groups' topics include science identity, mentoring, and metacognition. As an example, the self-titled "Scidentity" working group consists of two biologists, one biology education researcher, one social scientist, and one K-12 curriculum policy specialist. Members of this group reported to the iEMBER leadership that "the expedient manner in which the proposal was created, and clarity of the project's scope were direct results of having a working group with a diverse background." A purpose of future meetings as well as our interaction forum is to continue to foster the development of future research projects and collaborations.

The third step of iEMBER will be to connect with discipline-specific communities. The iEMBER community is multidisciplinary and multicultural in its mission to foster diversity, equity, and inclusion in the biological STEM enterprise. iEMBER would like to continue on this path of inclusion and collaboration by connecting with organizations across social sciences, biological sciences, and biology education. iEMBER members plan to continue having a presence at conferences and meetings sponsored by these fields (see Table 1). These kinds of collaborations will provide an institutionalization framework for iEMBER activities within larger scientific audiences. Such activities will also ensure that there are a variety of ways for iEMBER members to meet regularly and to be involved. 


\section{HOW TO CONNECT WITH US}

Interested individuals can learn more about iEMBER and request to join by visiting our website (http://iember.org). National iEMBER meetings will be held biennially, with the next meeting in April 2019 in St. Louis, MO. In addition to iEMBER's presence at upcoming national meetings, we are excited to connect with well-established communities and community members. We are aware that other organizations are also working toward broadening participation goals-Society for the Advancement of Chicanos and Native Americans in Science, Understanding Interventions that Broaden Participation in Science Careers; Center for Applied Special Technology-Universal Design for Learning, Quality Education for Minorities Network, and the Association of American Colleges and UniversitiesProject Kaleidoscope, to name a few. iEMBER seeks to support the efforts of individuals and organizations who are already engaged in this work and those who would like to be involved.

In summary, iEMBER is forming a collaborative network of stakeholders, including biology education researchers, social scientists, program directors, policy experts, and biologists with interests in diversity, equity, and inclusion. The iEMBER network will use existing social science research as fuel to start conversations and collaborative projects on assessing the environment of biology education and research spaces. Importantly, one primary lesson learned thus far is that there is a need for a network of this nature that is truly collaborative. Another lesson learned is that connecting across disciplines allows reflection on the similarities between biological, educational, and social sciences. When it comes to promoting diversity, equity, and inclusion, we found that biologists, biology educators, social scientists, program directors, and policy experts have much to learn from one another. iEMBER workshops, events, and projects will carve out the time, give focus, and supply interactions necessary for the development and assessment of new and applied ideas. We welcome all who share our interests and goals to join us as we strive to better serve our ever-growing and diversifying student populations.

\section{ACKNOWLEDGMENTS}

The iEMBER conference activities were funded by National Science Foundation Research Coordination Networks in Biology Undergraduate Education Incubator grant 1624169. We thank the additional NSF RCN-UBE Incubator grant co-principal investigators Dr. Richard Harvey and Dr. Uwe Hilgert for their efforts in conceptualizing and organizing the iEMBER network. We also thank members of the Future of Research board of directors for helpful discussions.

\section{REFERENCES}

Aguilar, L., Walton, G., \& Wieman, C. (2014). Psychological insights for improved physics teaching. Physics Today, 67(5), 43-49. https://doi .org/10.1063/PT.3.2383

AlShebli, B. K., Rahwan, T., \& Woon, W. L. (2018). Ethnic diversity increases scientific impact. Retrieved May 13, 2018, from https://arxiv.org/ abs/1803.02282

Bauerle, C. (2011). Vision and change in undergraduate biology education: A call to action, final report of a national conference. Washington, DC: American Association for the Advancement of Science.

Bensimon, E. M. (2005). The underestimated significance of practitioner knowledge in the scholarship on student success. Review of Higher Education, 30(4), 441-469. https://doi.org/10.1353/rhe.2007.0032
Dolan, E. L. (2013). Biology education research 2.0. CBE-Life Sciences Education, 14(4), ed1. https://doi.org/10.1187/cbe.15-11-0229

Dolan, E. L. (2017). Within and beyond biology education research: Steps toward cross-disciplinary collaboration. CBE-Life Sciences Education, 16(4), ed2. https://doi.org/10.1187/cbe.17-10-0224

Dye, K. M., \& Stanton, J. D. (2015). Metacognition in upper-division biology students: Awareness does not always lead to control. CBE-Life Sciences Education, 16(2), ar31. https://doi.org/10.1187/cbe.16-09-0286

Frost, S. H., \& Jean, P. M. (2001). Bridging the disciplines: Interdisciplinary discourse and faculty scholarship. Journal of Higher Education, 74(2), 119-149. https://doi.org/10.1353/jhe.2003.0013

Gibbs, K. D., Basson, J., Xierali, I. M., \& Broniatowski, D. A. (2016). Decoupling of the minority PhD talent pool and assistant professor hiring in medical school basic science departments in the US. eLife, 5, 1-20. https://doi .org/10.7554/eLife.21393

Graham, M. J., Frederick, J., Byars-Winston, A., Hunter, A. B., \& Handelsman, J. (2013). Increasing persistence of college students in STEM. Science, 341(6153), 1455-1456. https://doi.org/10.1126/science.1240487

Huerta, M. F., Farber, G. K., Wilder, E. L., Kleinman, D. V., Grady, P. A., Schwartz, D. A., \& Tabak, L. A. (2005). NIH roadmap interdisciplinary research initiatives. PLoS Computational Biology, 1(6), e59. https://doi.org/10.1371/ journal.pcbi.0010059

Hurtado, S., Eagan, K., \& Chang, M. (2010, January). Degrees of success: Bachelor's degree completion rates among initial STEM majors. Los Angeles: Higher Education Research Institute at UCLA. Retrieved May 13, 2018, from www.heri.ucla.edu/nih/downloads/2010\%20 -\%20Hurtado,\%20Eagan,\%20Chang\%20-\%20Degrees\%20of\%20Success .pdf

Meyers, L. C., Brown, A. M., Moneta-Koehler, L., \& Chalkley, R. (2018). Survey of checkpoints along the pathway to diverse biomedical research faculty. PloS ONE, 13(1), e0190606. https://doi.org/10.1371/journal.pone .0190606

Minority Postdoc. (2018, February 20). Diversity Stakeholders. Retrieved May 13, 2018, from www.minoritypostdoc.org/view/stakeholders.html

Morris, V. R., \& Washington, T. M. (2017). The role of professional societies in STEM diversity. Journal of the National Technical Association, 87(1), 2231. https://doi.org/10.1090/noti1642

Nager, M., Nelsen, C., \& Nouyrigat, F. (2011). Startup weekend: How to take a company from concept to creation in 54 hours. Hoboken, NJ: John Wiley \& Sons.

National Center for Education Statistics. (2013). STEM attrition: College students' paths into and out of STEM fields statistical analysis report. Washington, DC.

National Science Foundation, National Center for Science and Engineering Statistics. (2017). Women, Minorities, and Persons with Disabilities in Science and Engineering: 2017 (Special Report NSF 17-310). Arlington, VA.

Peffer, M., \& Renken, M. (2016). Practical strategies for collaboration across discipline-based education research and the learning sciences. CBE-Life Sciences Education, 15(4), es11. https://doi.org/10.1187/cbe.15-12-0252

Perna, L., Lundy-Wagner, V., Drezner, N. D., Gasman, M., Yoon, S., Bose, E., \& Gary, S. (2009). The contribution of HBCUs to the preparation of African American women for STEM careers: A case study. Research in Higher Education, 50(1), 1-23. https://doi.org/10.1007/s11162-008-9110-y

Pickett, C. L., Corb, B. W., Matthews, C. R., Sundquist, W. I., \& Berg, J. M. (2015). Toward a sustainable biomedical research enterprise: Finding consensus and implementing recommendations. Proceedings of the National Academy of Sciences USA, 112(35), 10832-10836. https:// doi.org/10.1073/pnas.1509901112

President's Council of Advisors on Science and Technology. (2012). Engage to excel: Producing one million additional college graduates with degrees in science, technology, engineering, and mathematics. Washington, DC: U.S. Government Office of Science and Technology.

Ribera, A. K., Miller, A. L., \& Dumford, A. D. (2015). Sense of peer belonging and institutional acceptance in the first year: The role of high-impact practices. Journal of College Student Development, 58(4), 545-563. https://doi.org/10.1353/csd.2017.0042

Roca, A.I. (2017, June 11) \#EMBER2017 workshop. Wakelet. Retrieved May 13, 2018, from https://wakelet.com/wake/ec4f20c2-35bf-4df0-bbcd -Obce99565b37 
Seymour, E., \& Hewitt, N. (1997). Talking about leaving: Why undergraduates leave the sciences. Boulder, CO: Westview Press.

Shin, J. E. L., Levy, S. R., \& London, B. (2016). Effects of role model exposure on STEM and non-STEM student engagement: Role model. Journal of Applied Social Psychology, 46(7), 410-427. https://doi.org/10.1111/ jasp.12371

Shipley, T. F., McConnell, D., McNeal, K. S., Petcovic, H. L., \& John, K. E. S. (2017). Transdisciplinary science education research and practice: Opportunities for GER in a developing STEM discipline-based education research alliance (DBER-A). Journal of Geoscience Education, 65(4), 354-362. https://doi.org/10.5408/1089-9995-65.4.354

Wang, M.T., \& Degol, J. (2013). Motivational pathways to STEM career choices: Using expectancy-value perspective to understand individual and gender differences in STEM fields. Developmental Review, 33(4), 304340. https://doi.org/10.1016/j.dr.2013.08.001

Yeager, D. S., \& Walton, G. M. (2011). Social-psychological interventions in education: They're not magic. Review of Educational Research, 81(2) 267-301. https://doi.org/10.3102/0034654311405999 